Esta publicación cientifica en formato digital es continuidad de la revista impresa ISSN-Versión Impresa 0798-1406 / ISSN-Versión on line 2542-3185Depósito legal pp
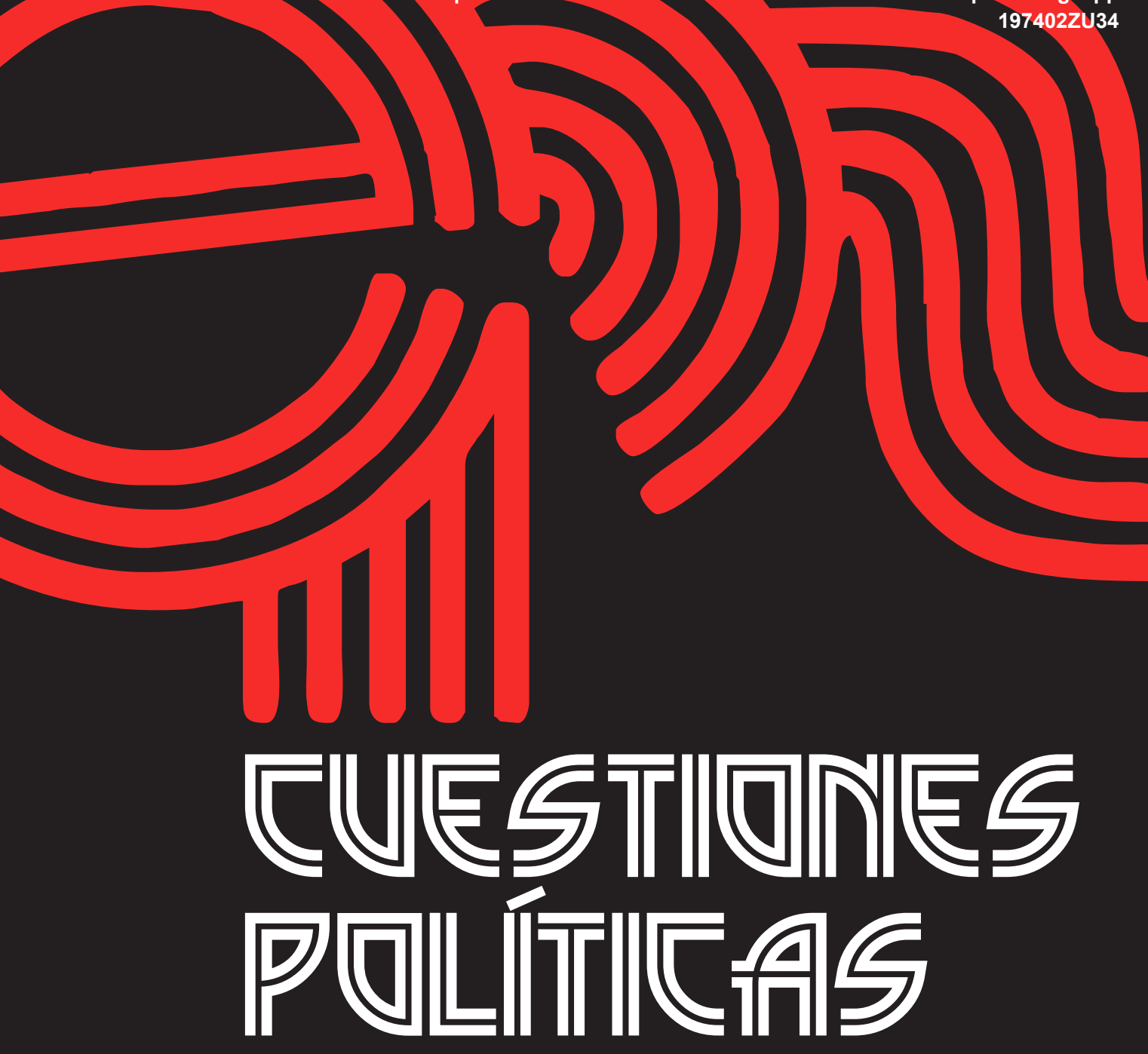

Instituto de Estudios Políticos y Derecho Público "Dr. Humberto J. La Roche" de la Facultad de Ciencias Jurídicas y Políticas de la Universidad del Zulia Maracaibo, Venezuela
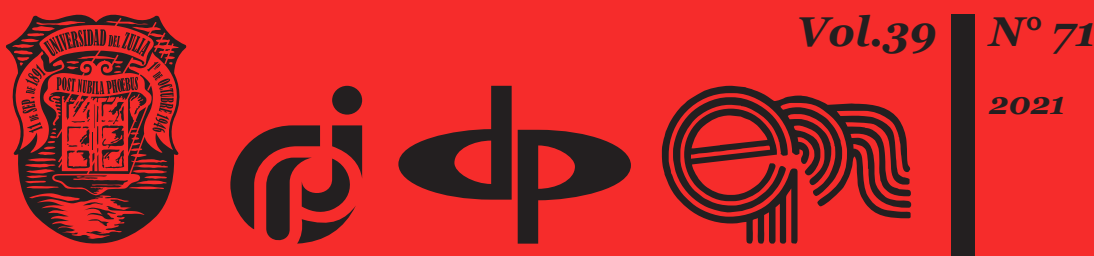


\title{
Disease prevention for the social and economic well-being
}

\author{
DOI: https://doi.org/10.46398/cuestpol.3971.57
}

\author{
Vasyl Shevchuk * \\ Pavlo Ivanchov ** \\ Igor Paryzkyi *** \\ Vitalii Maltsev **** \\ Vitaliy Oksin $* * * * *$
}

\begin{abstract}
The objective of the article was to analyze the socio-economic effectiveness of preventive measures of the main diseases of people of different age groups in the reality of Ukraine. The subject of the study is the characteristics of disease prevention for various age groups. The following research methods are used in the article: analysis and synthesis; systematization of theoretical and empirical research results; analogy and summary. As a result, the role of the prevention of major human diseases is clarified to ensure the socio-economic potential of countries, increase labour capital and productivity and, in addition, contribute to the expansion of gross domestic product. Prevention possibilities are characterized to reduce the burden of disease. At a practical level, comprehensive means of disease prevention are proposed for different age groups of the population. By way of reference, the conditions and possibilities of reducing the fatal outcomes of the main diseases inherent in the population of Ukraine, such as cancer and cardiovascular diseases, among others, are determined.
\end{abstract}

Keywords: public health policy; disease prevention; life expectancy; labour productivity; socioeconomic well-being.

* Doctor of Economics, Director General of the Center for Sustainable Development Studies, Ukraine. ORCID ID: https://orcid.org/oooo-0002-6634-723X

** Doctor of Medical Sciences, Head of Surgery Department №3 of O. Bohomolets National Medical University, Ukraine. ORCID ID: https://orcid.org/oooo-ooo1-62014203

*** Doctor of Economics, PhD in Law, Professor of the Department of Marketing, Economics, Management and Administration, Vice-Rector for Strategic Development of the Higher Educational Institution "National Academy of Management". Ukraine. ORCID ID: https://orcid.org/oooo-ooo1-6835-5930

**** PhD in Law, Senior Research Fellow of the Scientific Institute of Public Law, Ukraine. ORCID ID: https://orcid.org/oooo-0002-5052-2697

***** Doctor of Law, Leading Researcher of the Scientific Institute of Public Law, Ukraine. ORCID ID: https://orcid.org/oooo-0001-6080-7752 


\section{Prevención de enfermedades para el bienestar social y económico}

\section{Resumen}

El objetivo del artículo fue analizar la eficacia socioeconómica de las medidas preventivas de las principales enfermedades de personas de diferentes grupos de edad en la realidad de Ucrania. El tema del estudio son las características de la prevención de enfermedades para varios grupos de edad. En el artículo se utilizan los siguientes métodos de investigación: análisis y síntesis; sistematización de resultados de investigaciones teóricas y empíricas; analogía y resumen. Como resultado se aclara el papel de la prevención de las principales enfermedades humanas para garantizar el potencial socioeconómico de los países, aumentar el capital laboral y la productividad y, además, contribuir a la expansión del producto interno bruto. Se caracterizan las posibilidades de prevención para reducir la carga de morbilidad. A nivel práctico, se proponen medios integrales de prevención de enfermedades para diferentes grupos de edad de la población. A modo de conclusión se determinan las condiciones y posibilidades de reducción de los desenlaces mortales de las principales enfermedades inherentes a la población de Ucrania, como el cáncer y las enfermedades cardiovasculares, entre otras.

Palabras clave: política de salud pública; prevención de enfermedades; esperanza de vida; productividad laboral; bienestar socioeconómico.

\section{Introduction}

Health is a crucial factor of well-being and a fundamental human right; its protection, in addition to its social significance, has an important economic effect. Over the last century, improving health has been a critical driver of global growth, by stimulating the growth of the labour force and productivity.

The improvements in hygiene, nutrition, and the invention of antibiotics and vaccines over the past century have led to tremendous progress in global health; scientific and technological progress and continuous innovation have significantly contributed to a significant improvement in the survival rate of people with non-infectious diseases, especially cancer and cardiovascular diseases. This allowed life to be extended almost 2.5 times between 1800 and 2017 - from just over 30 years to 73 (McKinsey Global Institute 2020), thus increasing labor potential. 


\section{Vasyl Shevchuk, Pavlo Ivanchov, Igor Paryzkyi, Vitalii Maltsev y Vitaliy Oksin 944 \\ Disease prevention for the social and economic well-being}

As life expectancy increases, the working age of the population, its participation in social production also increases, which leads to higher economic efficiency of the countries. However, these conditions place new demands on the health care system to ensure high health status, as there is now a growing risk of premature death and the development of health problems that not only disrupt the normal functioning of people, but also prevent their full production potential. Given this, it is important to understand the importance of disease prevention in achieving the socioeconomic well-being of the country.

\section{Methodology}

The realization of the purpose of the article involves the use of the following research methods:

Theoretical method is used to review the relevant literature in order to study scientific sources and develop conceptual foundations of the research.

- The method of systematization of theoretical and empirical results of the study allows to determine the features of disease prevention to support the socio-economic well-being of the population.

- The method of analogy is applied to determine the effectiveness of preventive measures to preserve the health of people of different ages.

- The method of summarization makes it possible to formulate the conclusions deriving from this study.

- To consider the effectiveness of prevention of key diseases and the possibility of reducing the consequences of diseases, logical method is used.

The data of official reports of the State Statistics Service of Ukraine is analyzed with the help of statistical method.

\section{Literature Review}

The relationship between health and socio-economic issues has been in the attention of scholars and officials since the second half of the 2oth century, but in recent decades they have taken on special importance. The World Health Organization (WHO) stressed in 2009 on the need to assess health not only in terms of viability, but also in terms of social and economic opportunities. The WHO recommendations for identifying the economic consequences of diseases and injuries at both micro and macro levels, 
as well as the losses incurred by individuals, households, firms, and the state as a whole, formed the basis for the further in-depth theoretical and empirical research. At the same time, the scientists have analyzed various aspects of health and their impact on economic potential.

The economic impact of infectious diseases has been determined by international organizations (World Bank (2017) and WHO (2009)), as well as by some scientists (Saker et al. 2004; Parpia et al. 2016; AlfaroMurillo et al. 2016). Besides, many researchers (Egger 2009; Merkur, Sassi, and Mcdaid, 2015; Machalaba et al. 2017; Palamar \& Gruzeva 2018) have studied certain aspects of health and socio-economic consequences of certain infectious and non-infectious diseases. The threat of psychological disorders and diseases for human life and the economy as a whole was raised in the works by (McDaid, Park, and Wahlbeck 2019). The researchers of the American Heart Association and American Stroke Association (2017), as well as foreign scientists (Barolia et al. 2019; Archer, and Blair, 2011; Volpe, Battistoni et al. 2020; Chatterjee \& Cheng 2020) analyzed the cost of cardiovascular disease treatment and the possibilities of their prevention.

The empirical study by the Institute for Health Metrics and Evaluation (IHME) is important for the systematic analysis of the economic role of disease prevention. The IHME found that the global burden of disease (disability-adjusted life year) could be reduced by about $40 \%$ if standardized disease prevention measures and the most effective of the available tools were applied (Table 1). Thus, for middle-aged people, disease prevention can increase the number of healthy years by a decade (McKinsey Global Institute 2020).

Table 1. Opportunities to improve health status by preventing major diseases for different age groups

\begin{tabular}{|c|c|c|c|}
\hline Period & Risk for health & Preventive measures & $\begin{array}{c}\text { Potential } \\
\text { for disease } \\
\text { reduction, \% }\end{array}$ \\
\hline \multirow{3}{*}{ Pregnancy } & $\begin{array}{l}\text { Maternal and neonatal } \\
\text { diseases }\end{array}$ & $\begin{array}{l}\text { Safe delivery in hospital } \\
\text { with obstetric support } \\
\text { and appropriate care }\end{array}$ & 74 \\
\hline & $\begin{array}{l}\text { HIV/AIDS and sexually } \\
\text { transmitted infections }\end{array}$ & Antiretroviral therapy & 74 \\
\hline & $\begin{array}{l}\text { Genetic and birth } \\
\text { defects }\end{array}$ & $\begin{array}{l}\text { Pre-conceptional } \\
\text { prevention }\end{array}$ & 41 \\
\hline
\end{tabular}


Vasyl Shevchuk, Pavlo Ivanchov, Igor Paryzkyi, Vitalii Maltsev y Vitaliy Oksin

\begin{tabular}{|c|c|c|c|}
\hline \multirow{3}{*}{ o-14 years } & $\begin{array}{l}\text { Respiratory infections } \\
\text { and tuberculosis }\end{array}$ & $\begin{array}{l}\text { Integrated child } \\
\text { immunization } \\
\text { programme; Regular } \\
\text { clinical examinations }\end{array}$ & 81 \\
\hline & Meningitis and gepatitis & $\begin{array}{l}\text { Vaccination, access to } \\
\text { qualified treatment }\end{array}$ & 24 \\
\hline & Intestinal infections & $\begin{array}{l}\text { Healthy development } \\
\text { and sanitation }\end{array}$ & 24 \\
\hline \multirow{3}{*}{$\begin{array}{l}14-21 \\
\text { years }\end{array}$} & Bad habits & $\begin{array}{l}\text { Comprehensive } \\
\text { Programme to Reduce } \\
\text { Substance Abuse }\end{array}$ & 29 \\
\hline & Mental ilness & $\begin{array}{c}\text { Access to psychological } \\
\text { assistance }\end{array}$ & 18 \\
\hline & $\begin{array}{l}\text { Injuries and } \\
\text { interpersonal violence }\end{array}$ & $\begin{array}{l}\text { Review, education, } \\
\text { referral and treatment } \\
\text { for adolescents and } \\
\text { adults }\end{array}$ & 28 \\
\hline \multirow{4}{*}{$\begin{array}{l}21-60 \\
\text { years }\end{array}$} & Cancer & $\begin{array}{c}\text { Hepatitis B and C } \\
\text { vaccine, habit-free, } \\
\text { annual screening, early } \\
\text { detection and treatment } \\
\text { of breast cancer }\end{array}$ & $27-36$ \\
\hline & Cardiovascular diseases & $\begin{array}{l}\text { Comprehensive } \\
\text { cardiovascular } \\
\text { prophylaxis, including } \\
\text { drug use, lifestyle and } \\
\text { behavioural change, } \\
\text { specialized cardio }\end{array}$ & $31-39$ \\
\hline & $\begin{array}{l}\text { Musculoskeletal } \\
\text { abnormalities }\end{array}$ & $\begin{array}{c}\text { Weight control, } \\
\text { physiotherapy, } \\
\text { occupational health and } \\
\text { safety, sport }\end{array}$ & 34 \\
\hline & Mental illness & Psychotherapy & 15 \\
\hline \multirow{3}{*}{$\begin{array}{l}\text { After } 60 \\
\text { years }\end{array}$} & Cardiovascular diseases & $\begin{array}{c}\text { Comprehensive } \\
\text { cardiovascular } \\
\text { prophylaxis } \\
\text { and specialized } \\
\text { cardiovascular care }\end{array}$ & 40 \\
\hline & Cancer & $\begin{array}{l}\text { Adoption of a healthy } \\
\text { lifestyle }\end{array}$ & 29 \\
\hline & $\begin{array}{l}\text { Diabetes and kidney } \\
\text { disease }\end{array}$ & $\begin{array}{l}\text { Diabetes prevention } \\
\text { programme, including } \\
\text { awareness-raising, } \\
\text { weight control, } \\
\text { maintenance treatment }\end{array}$ & 33 \\
\hline
\end{tabular}

Developed by the Authors. 
Thanks to preventive measures, a global improvement of $\$ 12$ trillion, or just about $8 \%$ of world GDP can be achieved by 2040 . This is a consequence of changes in the labour market due to increased employment (Low rate of early death from cardiovascular diseases, cancer, malaria and other causes), reduction of periods of temporary disability due to health condition and higher involvement of healthy people in work process, improving physical and cognitive health of employees. Besides, higher economic efficiency is achieved due to the fact that older people can work longer, which reduces the need to care for the elderly and sick, and ensuring the health of children and adolescents has a positive impact on human development (McKinsey Global Institute 2020, pp. 87 - 90). Investment in maintaining and improving health has a significant rate of return of 2-4 times depending on the level of economic development.

Therefore, given the significant socio-economic impact of health on the quality of life and welfare of countries in general, the aim of the article is to analyze socio-economic effectiveness of measures to prevent major diseases of people of different ages in Ukraine.

\section{Results and Discussion}

The success of disease prevention depends on the effectiveness of preventive measures at all ages, starting with pregnancy planning. At this stage it is extremely important to go through the set of measures for preconception prevention - diagnosis and correction of the health of future parents. It should be started at least 3 months before the planned conception - that's how long it takes to undergo medical examinations and adjust your lifestyle and diet. If doctors find any diseases (such as TORCH infections) during the examinations, it will take some time to treat them. This approach to reproductive medicine will most likely count on a favorable pregnancy and the birth of a healthy baby.

Maintaining and improving children's health (o-14 years) is an important function of the State is a scientifically sound system of measures aimed at socio-legal (primary) and medical (secondary and tertiary) prevention of diseases in children age, which is implemented by public policy. The purpose of preventive pediatrics, including adolescence, is to organize and conduct an effective set of measures to preserve, improve and restore children's health, ensure normal growth and development of the child from the moment of family planning to the age of majority, providing medical care, social and mental well-being, social adaptation of the child, as well as the possibility of realizing personal potential according to age.

Prevention of diseases of people of working age is perhaps the most important task of the State, as the health of workers determines the quantity 


\section{8 \\ Vasyl Shevchuk, Pavlo Ivanchov, Igor Paryzkyi, Vitalii Maltsev y Vitaliy Oksin \\ Disease prevention for the social and economic well-being}

and quality of labor potential of the country, which ensures the welfare, economic growth, defense, and independence of the State (Shevchuk et al. 2016, p. 5). The mortality of people of working age significantly reduces the average life expectancy because in Ukraine; in particular, the total mortality of the population is mainly (38\%) $30-70$ of age. One third of the population does not live to the end of their working life (6o-65 years) (Saker et al. 2004). Thus, with the premature death of the population alone, the country loses about 4 million years of potential life and UAH 47.9 - 89.1 billion of the national product respectively, despite the fact that most losses are due to premature death of men. The diseases of the circulatory system, tumors, injuries, poisonings, and some other consequences of external causes are among the main causes of mortality among the working age population (Table 2).

Table 2. The causes of death in Ukraine, 2010-2019

\begin{tabular}{|c|c|c|c|c|c|c|c|c|c|c|c|}
\hline \multirow[b]{2}{*}{ Indicator } & \multicolumn{10}{|c|}{ Рік } & \multirow{2}{*}{$\begin{array}{c}\text { From } \\
2019 \\
\text { to } \\
2010, \\
+/-\end{array}$} \\
\hline & 2010 & 2011 & 2012 & 2013 & 2014 & 2015 & 2016 & 2017 & 2018 & 2019 & \\
\hline $\begin{array}{l}\text { Total death, } \\
\text { including } \\
\text { from: }\end{array}$ & 698235 & 664588 & 663139 & 662368 & 632296 & 594796 & 583631 & 574123 & 587665 & 581114 & -117121 \\
\hline $\begin{array}{l}\text { - certain } \\
\text { infectious } \\
\text { and } \\
\text { parasitic } \\
\text { diseases }\end{array}$ & 14642 & 14050 & 13922 & 12921 & 10974 & 9900 & 9326 & 8714 & 8964 & 8120 & -6522 \\
\hline - neoplasm & 88767 & 88957 & 92896 & 92337 & 83894 & 79530 & 78959 & 78324 & 78597 & 78223 & -10544 \\
\hline $\begin{array}{l}\text { - circulatory } \\
\text { system } \\
\text { diseases }\end{array}$ & 465093 & 440346 & 436445 & 440369 & 425607 & 404551 & 392298 & 384810 & 392060 & 389348 & -75745 \\
\hline $\begin{array}{l}\text { - respiratory } \\
\text { illnesses }\end{array}$ & 19480 & 17871 & 17109 & 16540 & 14810 & 13951 & 13840 & 12166 & 13006 & 12504 & -6976 \\
\hline $\begin{array}{l}\text { - diseases } \\
\text { of digestive } \\
\text { system }\end{array}$ & 26817 & 25230 & 27719 & 27953 & 25225 & 22818 & 22013 & 21999 & 24489 & 24144 & -2673 \\
\hline $\begin{array}{l}\text { - external } \\
\text { causes }\end{array}$ & 43955 & 42380 & 41713 & 40298 & 40135 & 34569 & 31746 & 31185 & 30905 & 30009 & -13946 \\
\hline
\end{tabular}

Developed by the Authors.

Therefore, we consider it important to prevent diseases at all stages of people's lives, which will contribute to the prevention, early detection, and timely treatment of diseases at the primary level of care, which will not only reduce the burden on the medical system but also the burden of disease. 
To preserve health, standardized protocols of medical supervision are created, active prevention of diseases of all age groups is carried out (the main measures are given in Table 3), the diagnostic base is developed; there is also a constant clinical introduction of fundamentally new, effective methods of treatment, which, on the one hand, generally reduces the incidence of disease and full recovery from severe illness without disability on the other one.

\section{Table 3. Main preventive measures for different age groups}

\begin{tabular}{|c|c|}
\hline Age group & Main preventive measures \\
\hline $\begin{array}{l}\text { Planning and } \\
\text { period of } \\
\text { pregnancy }\end{array}$ & $\begin{array}{l}\text { Pre-conception training includes: } \\
\text { - examination of parents for reproductive ability; } \\
\text { - general medical examination; } \\
\text { - using folic acid; } \\
\text { - HIV / AIDS screening and treatment (if necessary); } \\
\text { - screening for sexually transmitted infections and their } \\
\text { treatment; } \\
\text { - therapy in case of detection of various diseases; } \\
\text { - cessation of smoking and alcohol consumption; } \\
\text { - elimination of obesity, etc. } \\
\text { Prevention during pregnancy: } \\
\text { - ultrasound screening; } \\
\text { - hormonal background, blood, urine analysis, etc .; } \\
\text { - detection and treatment of infectious diseases; } \\
\text { - regular gynecological examination, etc. }\end{array}$ \\
\hline o-14 years & $\begin{array}{l}\text { Stages of preventive pediatrics: } \\
\text { - antenatal and intranatal prophylaxis. } \\
\text { - preventive work with children in the first year of life } \\
\text { and children of early age. } \\
\text { - preventive work with children in preschool, school, } \\
\text { including adolescence. } \\
\text { These measures include: } \\
\text { - assessment of physical development. } \\
\text { - assessment of psychomotor development. }\end{array}$ \\
\hline 14-21 years & $\begin{array}{l}\text { Annual preventive examinations by a dentist, } \\
\text { endocrinologist, pediatric surgeon, as well as a pediatric } \\
\text { / adolescent gynecologist (according to the indications), } \\
\text { child psychologist (according to the indications) include } \\
\text { - assessment of physical development. } \\
\text { - assessment of body mass index. } \\
\text { - assessment of neuropsychological development. } \\
\text { - passing fluorography. } \\
\text { - blood test (hemoglobin) and others according to the } \\
\text { indications. } \\
\text { - control of bad habits and diet, etc. }\end{array}$ \\
\hline
\end{tabular}


Vasyl Shevchuk, Pavlo Ivanchov, Igor Paryzkyi, Vitalii Maltsev y Vitaliy Oksin

\begin{tabular}{|l|l|}
\hline 21-6o years & The main preventive measures include: \\
& 1) Oncological screening: \\
& For women: \\
& -breast examination (one clinical examination per year, \\
& one mammography every two years) \\
- cytological diagnosis (PAP test) and human & papillomavirus test (HPV test) - once every 5 years. \\
& - fibrocolonoscopy - once every 5 years. \\
& - Fibrogastroduodenoscopy - once a year and when \\
& For men (after 40 years): \\
& - examination by urologist - once a year (PSA test if \\
& necessary); \\
& - fibrocolonoscopy - once every 5 years. \\
& 2) Treastroduodenoscopy - once a year. \\
& 3) Timely detection and treatment of chronic diseases. \\
4) Dental examination.
\end{tabular}

Developed by the Authors

Based on research by McKinsey Global Institute, we are convinced that these preventive measures of the most common diseases in Ukraine over the next 15 years will help to reduce cancer fatalities by $30 \%$, cardiovascular diseases - by $35 \%$, birth defects and certain conditions that occur in the perinatal period - by $74 \%$ (Fig. 1). 
Fig. 1. Potential for reducing mortality from major diseases in Ukraine by implementing preventive measures up to 2035

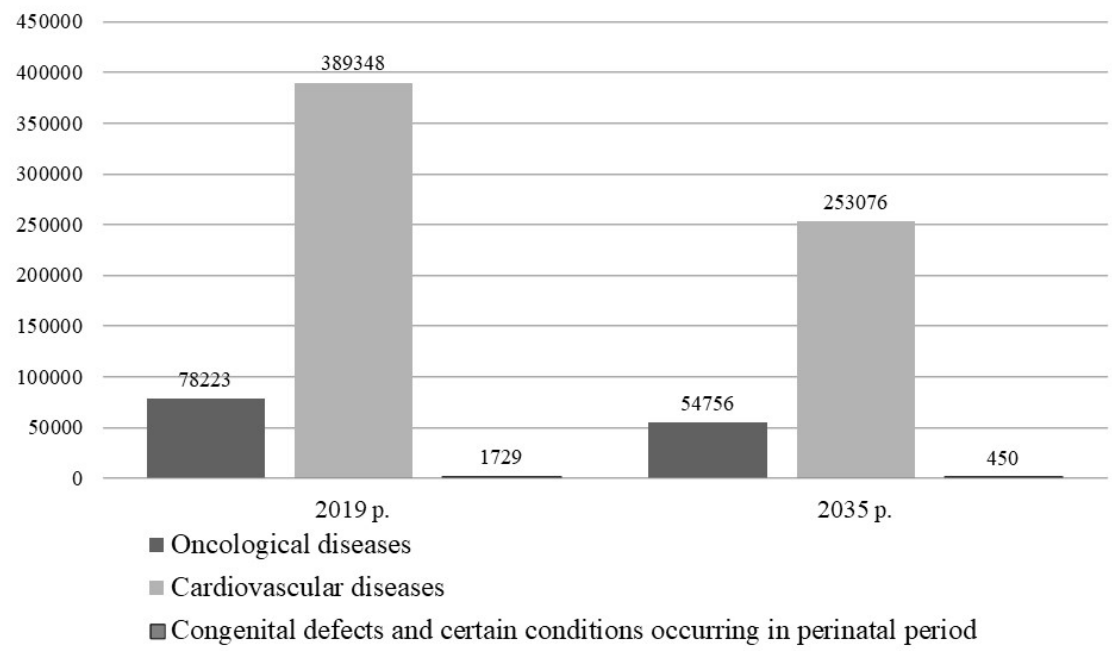

Developed by the Authors

The above preventive measures should be taken in the context of national environmental policy in order to continuously improve the environmental situation in the country for long-term synergies. One quarter of the population's health depends on the state of the environment, the harmonization of human life in the natural environment. High level of environmental pollution by harmful factors of physical, biological, chemical and other origin also causes the deterioration of the demographic situation and population health situation. Therefore, the improvement of air and drinking water quality in cities and villages, proper waste management, greening of the agro-industrial sector of the economy and other components of State environmental policy will help to reduce diseases and improve the socio-economic well-being of the population of Ukraine (Shevchuk et al., 2016).

Moreover, the improvement of health contributes to the growth of the country's economic potential due to reduced number of sick people and days of incapacity, thus, in the long run, GDP growth of the country can reach 8 per cent, that in the conditions of Ukraine could make an additional \$12.3 billion until 2035-2040. In view of this, disease prevention under current conditions plays a key role in achieving the socio-economic well-being of the country along with other factors of growth of the national economy. This problem is especially acute in developing countries due to low access 
of the population to health services (Giangaspero 2015). Therefore, the development of preventive medicine and primary care should play an important role in the process of transformation of the medical system. First of all, it is necessary to strengthen public administration of the country's medical system in order to:

1) create and implement targeted prevention programs with the support of the government, non-governmental organizations, private sector, and citizens of the country.

2) re-orient the health care system to identify risk groups, timely detect chronic diseases and conditions, as well as constant monitor their development.

3) introduce obligatory preventive examination of the working population with the involvement of the institution of family doctor, diagnostic centers, and social services in order to prevent the main classes of diseases.

4) improve the quality of medical services in hospitals of various forms of ownership on a market basis.

5) promote innovative and technological development of the medical sector by improving public administration, development of partnerships between the State, research organizations and medical institutions, the formation of appropriate financial and credit support and tax incentives (Paryzkyy 2018), etc.

The importance of maintaining high health status is at the forefront of research around the world (Egger 2009; Mcdaid, Sassi, and Merkur, 2015; Machalaba et al. 2017), but the considered theoretical and empirical achievements in this area relate to the analysis of the importance and forms of prevention of various diseases, which represent only a fraction of the threats to human beings, given their etiology and pathogenesis. Therefore, in contrast to the above issues, we proposed to consider a comprehensive approach to determining the importance of disease prevention for the socio-economic well-being of the population.

The problem of the impact of prevention of infectious and non-infectious diseases on the economy and general social welfare of people is thoroughly studied in the scientific literature (Parpia et al. 2016; Alfaro-Murillo et al. 2016; Palamar \& Gruzeva 2018). However, different, and sometimes incomplete methodological approaches are used to determine the costeffectiveness of disease prevention. The researchers do not pay attention to the detailed analysis of the system of preventive measures, through which it is possible to achieve high socio-economic effects in their scientific papers.

The difference between our study and the existing ones is the formation of a detailed set of preventive measures for different age groups, in 
particular in the following categories: pregnancy planning and the period of pregnancy; 0-14 years; 14-21 years; 21-60 years; after 60 years. The choice of such a gradation of age periods is associated with different levels of population participation in the economic processes of the country. At the same time, special attention is paid to the prevention of diseases among the working and elderly population, on whose health the socio-economic well-being of the country depends to a greater extent; the list of mandatory examinations and their frequency are clearly defined.

The practical value of the study is the identification of the potential impact of preventive medicine. Considering the most common diseases in Ukraine (cardiovascular, cancer and congenital malformations and other pathologies that occur in the perinatal period), the potential to avoid the serious consequences of these diseases, which can reduce mortality by more than $30 \%$, are identified.

The probable level of growth of the economic effect of improving public health due to better disease prevention is established, although the methodological support for such assessment is somewhat complicated due to the lack of international statistics on socio-demographic indicators and public health in Ukraine.

\section{Conclusion}

Preventive measures are an important priority of public administration, as they guarantee the right to healthy life, but also ensure economic growth by improving labor participation, increasing productivity, reducing the cost of therapy and care for the elderly. Global experience indicates that this achieves higher socio-economic prosperity, as it reduces the burden of disease and promotes greater domestic gross domestic product.

The main risks to the health, ability to work and life of the population in Ukraine, including diseases of the circulatory system, neoplasms, injuries, poisoning and some other external causes are identified. Therefore, it is especially important to maintain health at all stages of human life, which allows you to achieve long and prosperous life.

The authors' recommendations for the prevention of diseases of the population of different age groups, which can have a positive impact on Ukraine by reducing the effects of cardiovascular disease, cancer and birth defects and other pathologies that occur in the perinatal period, are formulated. Therefore, the systematization of the recommended preventive measures for all age groups proposed in the article has a significant practical significance and determines the empirical value of the work. 


\section{4 \\ Vasyl Shevchuk, Pavlo Ivanchov, Igor Paryzkyi, Vitalii Maltsev y Vitaliy Oksin Disease prevention for the social and economic well-being}

We see the prospects for further research in the detailed analysis of economic effect of maintaining public health, which lies in the development of the relevant methodological support.

\section{Bibliographic References}

ALFARO-MURILLO, Jorge; PARPIA, Alyssa; FITZPATRICK, Meagan; TAMAGNAN, Jules; MEDLOCK, Jan; NDEFFO-MBAH, Martial; FISH, Durland; ÁVILA-AGÜERO, María L; MARÍN, Rodrigo; KO, Albert I; GALVANI, Alison P. 2016. "A cost-effectiveness tool for informing policies on Zika virus control" In: "PLOS Neglected Tropical Diseases", Vol. 10, No. 5. Available online. In: https://doi.org/10.1371/journal. pntd.0004743. Date of consultation: 12/03/2021.

AMERICAN HEART ASSOCIATION AND AMERICAN STROKE ASSOCIATION. 2017. cardiovascular disease: A Costly Burden for America Projections Through 2035. Available online. In: https:// www.heart.org/-/media/files/get-involved/advocacy/burden-reportconsumer-report.pdf?la=en. Date of consultation: 12/03/2021.

ARCHER, Edward; BLAIR, Steven. 2011. "Physical activity and the prevention of cardiovascular disease: from evolution to epidemiology" In: Progress in Cardiovascular Diseases, No. 53, pp. 387-396.

BAROLIA, Rubina; HIGGINBOTTOM, Gina; DUGGLEBY, Wendy; CLARK, Aleksander. 2019. "Critical Challenges of Economic and Social Issues in Secondary Prevention of Cardiovascular Disease" In: Journal of Family Medicine and Disease Prevention, No. 5. Available online. In: https://doi. org/10.23937/2469-5793/1510105. Date of consultation: 12/04/2021.

CHATTERJEE, Neal; CHENG, Richard. 2020. "cardiovascular disease and COVID-19: implications for prevention, surveillance and treatment". In: BMJ, Vol. 106, No. 15, pp. 1119-1121. Available online. In: https://doi. org/10.1136/heartjnl-2020-317110. Date of consultation: 12/04/2021.

EGGER, Garry. 2009. "Health, "illth" and economic growth: medicine, environment, and economics at the crossroads" In: American Journal of Preventive Medicine. Vol. 37, No. 1, pp. 78-83.

GIANGASPERO, Massimo. 2015. "Family medicine and disease prevention: core topics for modern and healthy society". In: Journal of Family Medicine and Disease Prevention. Vol. 1, No. 1. Available online. In: https://clinmedjournals.org/articles/jfmdp/jfmdp-1-oo1e.pdf. Date of consultation: $12 / 04 / 2021$. 
MACHALABA, Catherine; SMITH, Kristine; AWADA, Lina; BERRY, Kevin; BERTHE, Franck; BOULEY, Timothy. 2017. "One health, economics to confront disease threats" In: Transactions of the Royal Society of Tropical Medicine and Hygiene. Vol. 111, No. 6, pp. 235-237.

MCDAID, David; PARK, A-La; WAHLBECK, Kristian. 2019. "The Economic Case for the Prevention of Mental Illness" In: Annual Review of Public Health. Vol. 40, pp. 373-389.

MCDAID, David; SASSI, Franko; MERKUR, Sherry. (eds). 2015. "Promoting Health, Preventing Disease: The Economic Case. UK higher education humanities \& social sciences health \& social welfare” In: Maidenhead, UK: Open University Press. Available online. In: https://www. euro.who.int/__data/assets/pdf_file/ooo6/283695/PromotingHealth-Preventing-Disease-Economic-Case.pdf. Date of consultation: 12/04/2020.

MCKINSEY GLOBAL INSTITUTE. 2020. Prioritizing health: A prescription for prosperity. Available online. In: https://www.mckinsey.com/ / media/mckinsey/industries/public\%20and\%20social\%20sector/ our\%20insights/prioritizing\%2ohealth\%20a\%2oprescription\%20 for\%2oprosperity/mgi_prioritizing\%2ohealth_report_july\%202020. pdf?shouldIndex=false. Date of consultation: 12/04/2020.

NAGORNAYA, Antonina; BASANETS, Anzhela; KONONOVA, Iryna; MEDVEDOVSKAYA, Nataliia; HVOZDETSKY, Viktor. 2021. "The state of health of the working age population and the effectiveness of the health care system of Ukraine" In: Ukraine. Health of the nation. Vol. 1, No. 1, pp. 5-22. Available online. In: http://webcache.googleusercontent. com/search?q=cache:qbKz8qKAi1EJ:healty-nation.uzhnu.edu.ua/ article/view/227145/228265+\&cd=1\&hl=ru\&ct=clnk\&gl=ua. Date of consultation: 04/04/2021.

PALAMAR, Boris; GRUZEVA, Tetiana. 2018. "Criteria of economic effectiveness of preventive measures of chronic non-infectious disease" In: Medical News. Vol. 71, No. 4, pp. 897-906. Available online. In: http:// ir.librarynmu.com/bitstream/123456789/975/1/WL\%2004\%202018_ Pal\%26Gr.pdf. Date of consultation: 04/04/2021.

PARPIA, Alyssa; NDEFFO-MBAH, Martial; WENZEL, Natasha; GALVANI, Alison P. 2016. "Effects of response to 2014-2015 Ebola outbreak on deaths from malaria, HIV/AIDS, and tuberculosis, West Africa" In: Emerging Infectious Diseases. Vol. 22, No. 3, pp. 433-441. Available online. In: https://doi.org/10.3201/eid2203.150977. Date of consultation: 04/04/2021. 
Vasyl Shevchuk, Pavlo Ivanchov, Igor Paryzkyi, Vitalii Maltsev y Vitaliy Oksin
956 Disease prevention for the social and economic well-being

PARYZKYY, Igor. 2018. "State Policy of Innovative Development of National Economy: Situation and Issues of Implementation" In: Journal of Advanced Research in Law and Economics. Vol. 9, No. 8, pp. 2721-2732. Available online. In: https://journals.aserspublishing.eu/jarle/article/ view/4129. Date of consultation: 04/04/2021.

SAKER, Lance; LEE, Kelley; CANNITO, Barbara; GILMORE, Anna; CAMPBELL-LENDRUM, Diarmid. 2004. "Globalization and infectious diseases: a review of the linkages" In: Special topics, No. 3. Available online. In: http://www.who.int/tdr/publications/documents/seb_ topic3.pdf. Date of consultation: 04/01/2021.

SHEVCHUK, Vasyl; CHERNYAK, Volodymyr; KOVALCHUK, Tetiana; PEDAN, Maryna; PANKOV, Oleh. 2016. "The development for salvation" In: Kyiv: Geoprint. Available online. In: https://drive.google.com/ file/d/oB8cWbMtimZymeG1rVHVsOERncm8/view?resourcekey=oSK8nqUGJD_wl1XSHHB81Qw. Date of consultation: 04/01/2021.

VOLPE, Massimo; BATTISTONI, Allegra; BELLOTTI, Paulo; BELLONE, Simonetta; BERTOLOTTI, Marko. 2020. "Recommendations for cardiovascular prevention during the sars-cov-2 pandemic: an executive document by the board of the Italian society of cardiovascular prevention" In: High Blood Press Cardiovascular Preview, No. 27, pp. 373-377. Available online. In: https://doi.org/10.1007/s40292-020-00401-1. Date of consultation: 04/01/2021.

WORLD BANK. 2017. "From panic and neglect to investing in health security: financing pandemic preparedness at a national level, international working group on financing preparedness" Available online. In: http:// documents1.worldbank.org/curated/en/979591495652724770/ pdf/115271-REVISED-FINAL-IWG-Report-3-5-18.pdf. Date of consultation: 04/01/2021.

WORLD HEALTH ORGANIZATION. 2009. WHO guide to identifying the economic consequences of disease and injury. Available online. In: http://www.who.int/choice/publications/d_economic_impact_guide. pdf. Date of consultation: 15/01/2021. 

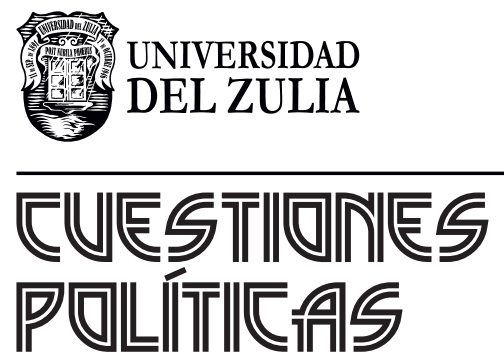

Vol. 39 N $^{\circ} 71$

Esta revista fue editada en formato digital y publicada en diciembre de 2021, por el Fondo Editorial Serbiluz, Universidad del Zulia. Maracaibo-Venezuela 